\title{
Conscious Consumption: A Study on Plastic Bags' Consumers in Brazil
}

\author{
Isabela Valdetaro Avallone \\ Faculty of Economics, Management and Accounting of Ribeirão Preto (FEA-RP) \\ Univerity of São Paulo (USP) \\ Av. Bandeirantes 3900, Monte Alegre, Ribeirão Preto (SP) 14040-905, Brazil \\ Tel: 55-16-3602-3903 E-mail: isabela.avallone@braskem.com.br \\ Janaina de Moura Engracia Giraldi (Corresponding author) \\ Faculty of Economics, Management and Accounting of Ribeirão Preto (FEA-RP) \\ Univerity of São Paulo (USP) \\ Av. Bandeirantes 3900, Monte Alegre, Ribeirão Preto (SP) 14040-905, Brazil \\ Tel: 55-16-3602-4970Ｅ-mail: jgiraldi@usp.br \\ Sonia Valle Walter Borges de Oliveira \\ Faculty of Economics, Management and Accounting of Ribeirão Preto (FEA-RP) \\ Univerity of São Paulo (USP) \\ Av. Bandeirantes 3900, Monte Alegre, Ribeirão Preto (SP) 14040-905, Brazil \\ Tel: 55-16-3602-4751_E-mail:soniavw@terra.com.br
}

Received: December 13, 2011

doi:10.5539/ijps.v4n1p122
Accepted: January 29, $2012 \quad$ Published: March 1, 2012

URL: http://dx.doi.org/10.5539/ijps.v4n1p122

\begin{abstract}
In a context where planet sustainability is brought into vogue, this study aimed to clarify issues such as the socio-demographic profile of those who do not have rigid views and beliefs regarding the benefits of consuming plastic bags, as well as relations between the degree of ecological consciousness and the adoption of sustainable practices. The method consisted of a simple transversal survey method, and the central hypothesis was that most of the respondents attribute a high importance to plastic bags. Factor analysis was used for data reduction; cluster analysis was employed to reveal distinct groups of consumers according to importance attributed to plastic bags; and cross-tabulation was used for determining the existence of differences among subgroups in demographic terms. Results were that most respondents attributed high importance to plastic bags, but half of them attributed low importance to it, while others attributed median importance.
\end{abstract}

Keywords: Conscious consumption, Green marketing, Plastic bags, Brazil

\section{Introduction}

The consumer behavior study area blends elements from psychology, sociology, social anthropology and economics, in an attempt to understand the buyer decision making process, both individually and in groups. Although psychology and economics are both disciplines that have to do with choice, and some of the fundamental theory of choice is common to them (Lea, 1978), Swait and Adamowicz (2001) explain that, while research in psychology field has largely employed controlled experiments to assess effects of choice context on choices and decisions, the economics field has tended to employ "natural experiments" arising from market data or stated preference data and incorporated context effects. Common to both areas of study, is the current concern for environmental friendly behavior and its impacts on consumer patterns, including the issue of packaging, 
since it accounts for a significant proportion of the resources consumed and waste generated by our consumer lifestyles (Ritch, Brennan \& MacLeod, 2009).

Ritch et al. (2009) indicates that, among the packaging concerns, the plastic bag use has become a focus of attention for government, business and community activists, which strive to find ways in which consumer behavior can be modified to reduce plastic bag use. Since the invention of plastic in 1862 by Alexander Parkes (Fabro, Lindemann, \& Vieira, 2007), modern civilization has been enjoying a series of economical and commercial benefits related to such material. However, it can be said that, in general, the present concerns regarding plastic disposal have hid the vantages of its use in manufacturing, leading to a view of plastic as a large environmental offender (Canevarolo Jr, 2004).

The elevated rate of plastic bags' consumption in Brazil is noteworthy in a context in which big natural catastrophes show nature's exhausting due to man's action (Albuquerque, 2009). Such consumption has become a habit which, in the long run, leads to alarming consequences, turning consumers as passive collaborators in a situation of environmental fragility (Fabro et al., 2007).

Nowadays, more and more people and institutions are in search for a balance with both their communities and other contexts, which can be directly or indirectly affected by the former (Albuquerque, 2009), adhering to fundaments of social and environmental responsibility. Indeed, new concerns of ethics and responsibility have been introduced and spread worldwide, by either option or even by the present context's claims regarding ecosystem and ecological sustainability issues (Demajorovic, 2003).

Nonetheless, it can be perceived that there is much to be done on promoting and enhancing the internalization of socio-environmental concepts among Brazilian consumers, given that they attribute excessive importance to plastic, as noted by Fabro et al. (2007), who report that $76.3 \%$ of the consumers face such product as an essential item in Brazilian commercial establishments.

In 2007 only, about 18 billion plastic bags were produced in Brazil (Bizzotto, 2009), most of them made from oil. Considering that this material's natural decomposing takes thousands of years, measuring the cumulative effects of plastic bags on nature becomes intuitive and alarming at the same time. Efforts to develop alternative materials that are less aggressive to the environment, such as oxybiodegradable, biodegradable and returnable ones, have been valorized by conscious corporations, institutions and authorities (Albuquerque, 2009).

Somehow, people will have to turn their consuming acts into strategies for reverting the current status of the planet. People will have to regularly worry about obtaining information regarding the products they are buying (Shurum, Mccarty, \& Lowrey, 1995), in order to become conscious consumers. Such consumers are more careful and concerned about details; in general, they look for products that cause less or no aggression to the environment (Ottman, 1994). In a few words, they conscientiously aim to produce null or favorable effects in the environment and society as a whole through their behavior (Lages \& Vargas Neto, 2002).

Conscious consumption has become an alternative to foment big changes in an impetuous future that threatens humanity's survival. Within this context, the problem investigated in the present study is as follows: Which is the importance attributed by consumers from a city in the countryside of the Brazilian state of São Paulo to plastic bags?

The present study is relevant for a series of knowledge fronts, as it sums to the arsenal regarding the research's subject, with perspectives related to the degree of ecological consciousness, as well as to the profile and adoption of sustainable practices and importance attributed by part of the consumers to such issues, as well as criteria utilized for opting to consume such product. The present data can, then, fundament other research and motivate businessmen, politicians and even citizens to question themselves and, possibly, reconsider the way they make choices and consume, as social actors. Below, the concepts that provide the background for the present study are presented.

\section{The Impact of Human Action on the Planet}

There are two clear positions about the impact of the human action on the planet (Caridade, 2006). The first one points out that science and technology together will be able to identify unambiguous solutions for the inert problem of natural resources' use; also, this positions affirms that estimating the limit of such resources cannot be done in a precise way. On the other hand, another expressive position emphasizes the vulnerability of natural resources in face of the accelerated growth and globalization. This position also clarifies that the available resources are enough, provided they are well managed and conscientiously utilized (Nobre \& Amazonas, 2002).

The present study is grounded in the second premise, which seems to be the most representative one in the current context. Also, it is observed that human actions related to economical growth have been causing more 
frequent and alarming problems (Caridade, 2006), such as global warming, desertification, acid rain, pollution, misery and social inequality (Hopwood, Mellor, \& O'brien, 2005). Moreover, such premise grounds the following discussion regarding conscious consuming and its need for keeping the planets' order and balance.

The world is in a fundamentally capitalist period; such productive system is based, among other principles, in the private property of means of production, the quest for profit as the springboard of development, and free initiative (Albuquerque, 2009). Within this context, production only makes sense if consumption occurs. The demand for more products has grown with population increase, which, along with the quest for profit, has been imposing higher volumes of production.

In order to do so, producers adopt more and more modern technologies and production techniques, which promise to enhance the efficiency of the production chain, so that higher and higher demands can be attended (Albuquerque, 2009). On the other hand, such demands exert controversial effects on this system's balance, representing man's depredatory action. Such process is being reproduced worldwide in different forms over societies and the environment, trespassing both geographic and temporal frontiers (Caridade, 2006).

Briefly, it can be said that the accelerated increase of consumption in an unprecedented way has been submitting the environment and biomes to a bulky pressure, compromising its balance and perpetuity and leading to the most diverse effects related to man's direct action over nature. Some authors reveal, however, that the awakening of a new consumers' consciousness would be able to lead to a change of consuming habits, which is indispensable for the planet's sustainability. Such awakening could, then, revert the current status of irresponsible management of natural resources (Caridade, 2006).

According to Tinoco (2004), the main environmental macro-problems currently are the increase of global temperature, the progressive destruction of the ozone layer and biodiversity (including species' extinction), industrial pollution and non-availability of drinking water. Such problems' dimension was discussed by Montaigne (2002), who revealed that about 80 children die each 20 minutes due to lack of drinking water or sanitation, and 9.3 thousand people die every day in poor countries, due to contaminated-water-related diseases, such as diarrhea, cholera, schistosomiasis and others.

Accounting all damage inflicted to the planet is a complex and uninterrupted task. It is difficult to estimate the negative effects of human action over the ecosystem in its magnitude and depth. However, it is clear that the planet has reached a saturation state, in which the most diverse demonstrations of nature's strength, such as storms, blizzards, floods and others, reveal that something must be done for life's balance and sustainability. Moura (2003) estimates that, in the present days, humanity has surpassed the ecosystems' regenerative capacity in $20 \%$, which serves as an alert for everyone.

From the information presented above, it can be concluded that man interferes directly in the environment through his actions. Considering that the ecosystem has been showing signals of exhaustion and depletion, the attention of an increasingly larger number of persons has been focused in environmental issues.

\section{Conscious Consumption and the Green Consumer}

Consuming is part of everyday life of all human beings with needs and wishes, although it may happen without notice (Barbosa, 2004). As such process seems automatic most of times, its importance is only perceived when issues such the effect of human action over the planet's future become frequent and concern the conscience of social actors.

Consuming brings several environmental impacts, varying in depth and dimension. From the use of water for product discarding to the need of electrical energy for production (Bertolini \& Possamai, 2005), consuming involves a series of steps toward the final product, which are not noticed by many people, who tend not to consider everything that was necessary and utilized in order to achieve what is offered in the end of such events' chain. It is observed that consuming has been increasing progressively sideways with population growth, the increase of income power and bigger marketing efforts. Along with this, concerns arise regarding the implications of human action over economy, society and nature (Albuquerque, 2009).

Even though consuming is an instrument for well-being, it is necessary that people get conscious and learn how to do so, in order to turn consuming into an agent for change (Caridade, 2006). Considering that the current models for production and consuming contribute for the deterioration of environmental balance and for the increase of some aspects of social inequality (Albuquerque, 2009), the change and learning of new habits and models is necessary to revert such situation.

A small part of the Brazilian population (5\%) has been developing their conscience on the proportion of consuming habits over human species' and the planet's life in general (Instituto Akatu, 2010). They turn their 
consuming choices into strategies for helping to build a better world in social and environmental terms. They adopt what is being called "conscious consuming", which consists of an attitude associated to environmental preservation and characteristically more selective in several aspects related to products, brands and companies (Raposo, 2003).

The concept shown above can be defined as an option of maximizing the positive impacts related to consuming and minimizing its negative ones (García, Durana, Abando, \& Molina, 2003). In other words, conscious consuming is related to a giving attention to the impacts of consuming over the planet and is oriented to sustainability. Conscious consumers, by doing so, look for balancing personal satisfaction with the planet's sustainability through a social, environmental and economical reflection, even though such transformations seem irrelevant for people who are indifferent to ecosystem-related issues. Conscious consuming emphasizes sustainability by supporting recycling, the use of clean technologies, waste reduction and the increment of a green market (Bertolini \& Possamai, 2005).

Generally, such consuming is related to simple, everyday attitudes, considering products or services buying, using and discarding, as well as choosing companies according to the their socio-environmental policies. Attending "green consumers" has become essential for elucidating different consuming patterns, given that the sustainable verve has started to fundament behaviors and attitudes of a part of the population who, through their choices and decisions, act as agents for the maintenance and perpetuity of life in their contexts.

Green consuming can refer to countless things; in every context, though, it involves discourses that point to alternative ways of buying, other than the ones currently regarded as reference. They range from buying products involving fair commerce practices to consuming organic food. In essence, green consumers have necessarily incorporated an environmental dimension in their attitudes and values, so that they adopt an activity pattern that does not contribute to the environment's progressive degradation (Gilg, Barr, \& Ford, 2005).

Consumers have become more and more interested in the origin of products they buy, due to specific green concerns or simply health and security-related ones. Such concerns are related to the way products are made, prepared and distributed, as well as their environmental handling and implications (Chryssohoidis \& Krystallis, 2005). These consumers demand from companies and entities information that is more and more transparent, so that the former can take more conscious, consistent decisions. In the present study, particularly, the authors focused the analysis on practices that are either directly or indirectly related to products and their uses, with an emphasis on sustainability.

In order to fundament the assessment of environmental concern's degree (which may influence consuming), Bertolini and Possamai (2005) proposed an analytical instrument based on the Quality Profile model (Gale, 1996) and Likert scales. After a bibliographic research on the concept of conscious consuming, Bertolini and Possamai (2005) built an instrument composed of 20 closed questions and a single open one, from which 4 closed questions were not used in the present study due to methodological issues, that is, they were not representative for the aims herein designed.

\section{The Context of Plastic Bags in Brazil}

Human evolution is noticeably associated to the development of plastic, which renders essential for modern life, due to either its physical or mechanical properties (Canevarolo Jr, 2004). Plastic is an expressive material in the current context and cannot be subdued. Among its many benefits for its higher use in industry, are its properties: highly resistant, light, low-cost, safe, chemically inert, does not create mold or contaminates water and is a good and flexible thermal, electric and acoustic insulator (Fabro et al., 2007). Besides this, plastic is a 100\% recyclable raw-material, which is relevant when considering the environmental effects of materials that are indiscriminately used worldwide, due to accelerated growing.

Unlike what is observed in most parts of the world, some European cities (German overall) found a viable alternative for surpassing the cumulative problem of discarded plastic bags. Specifically in Germany, consumers have started being charged for each plastic bag, giving them the option for its use, which has lead to a large substitution of plastic bags for cloth-made ones and cardboard boxes for product transport. By doing so, the problem was minimized, as citizens were induced to reflect on their environmental conscience (Fabro et al., 2007).

Ireland, which pioneered decisions regarding the product and unregulated use of plastic bags, created a tax called PlasTax in 2002, which in its turn demanded charging $€ 0.15$ for each distributed plastic bag. Through such tax, 23-million Euros were collected that year, which were integrally invested in environmental projects, besides a 90-percent decrease in the consumption of plastic bags. 
An alternative that can be adopted for reducing the plastic bags' problem regards creating new laws. In South Africa, a regulation was made, which considers the use of bags with less than 30 micrometers thick as illegal, in order to promote more resistant (and expensive) bags, so that their reuse is viable. Even more aggressive attitudes were observed in Bangladesh and the Indian state of Himachal Pradesh, where the production, acquisition and consuming of polyethylene bags is strictly prohibited, with high-cost fines to prison (in case of relapse) being predicted as punishments.

When qualitative data is analyzed, the dimension of Brazilian consumption of plastic bags is noticeable, as well as its responsibility over environmental problems that ravage the whole country. Only supermarkets distribute a billion plastic bags every month, from which $80 \%$ arrive in landfills as packages for all kinds of household garbage, including food scraps, empty packages and so forth (Bizzotto, 2009). In 2007, Brazil produced approximately 18 -billion plastic bags made from polyethylene, a product originated from oil that takes about 500 years to decompose.

\section{Methodology}

The present study is a descriptive, quantitative investigation, considering its aims. The method utilized consisted of a simple transversal survey method (Malhotra, 1996), with the following suggested hypotheses:

Central Hypothesis: Most of the respondents attribute a high importance to plastic bags, displaying a high level of involvement in its consumption's process.

The study's central hypothesis is grounded in an investigation by Fabro et al. (2007), who showed that $76.3 \%$ of Brazilian consumers consider plastic bags as an essential item in shops. The hypothesis above is related to the secondary destination a portion of the population gives plastic bags, that is, their use as household garbage bags. Thus, giving up their use does not seem as an easy or fast-adhesion task, as it implicates in extra costs for household income, as well as to the conversion and change of values.

Secondary hypothesis 1: Most of plastic bags consumers do not know environmental problems in depth.

When considering environmental catastrophes with worldwide impact and the frequent demonstrations of nature's depletion, people started to pay more attention to issues related to environment and the planet's capacity of sustain itself along time (Albuquerque, 2009). However, the hypothesis abovementioned takes into consideration that most of those who consume plastic bags are not environmentally conscious and do not know problems related to such issue in depth. So, they tend to absent themselves from their responsibility as social agents for the planet's conservation.

Secondary hypothesis 2: Respondents that attribute less importance to plastic bags are younger, have more study years and higher income than the other ones.

It can be deduced that in countries whose HDI (Human Development Index) is higher, there are more chances that education and development of citizenship is successful, leading to a higher consciousness over the planetary impacts of consumption behaviors. Thus, it may be possible to relate variables such as income and study-years to environmental consciousness and responsibility. The higher the former variables, the higher is the probability that conscious consumption is present in people's habits and routines.

Secondary hypothesis 3: There is no clear relationship between respondents' degree of involvement in the consumption of plastic bags and respondents' adoption of sustainable practices.

Such hypothesis is grounded in the speculation that plastic bags' consumers can display habits and behaviors related to environment preservation, even though they do not adopt sustainable practices related to such bags.

Secondary hypothesis 4: Most of respondents opt for plastic bags due to their gratuity and plausibility for household reuse.

Considering that German shops charge their clients for plastic bags, and that is this country, the consumption of plastic bags has reduced since such policy was adopted, it can be inferred that one of respondents' consumption criteria is the product's lack of cost. Additionally, as discussed above, many consumers relate plastic bags to their possible household use.

In order to verify the hypothesis herein presented, a questionnaire was elaborated for measuring the degree of importance attributed by respondents to plastic bags, among other secondary variables. For the present study specifically, the questionnaire developed by Bertolini and Possamai (2005) has shown to be consistent with the study's aim. In order to complement such instrument, new questions were added; its final version was pre-tested in a sub-sample $(\mathrm{n}=10)$ from the sample herein studied. 
In the present study, the population was defined as people who usually come to a hypermarket in a city of the countryside of the Brazilian state of São Paulo, with more than 600 thousand inhabitants. Such public include varied socioeconomic classes, who are possibly very frequent users of plastic bags. A non-probabilistic, convenience sample methodology was adopted, with a resulting $n=100$ part of the population.

In order to find an answer for the study's problem, the following strategies were employed: factor analysis for data reduction; cluster analysis, in order to reveal distinct groups of consumers according to importance attributed to plastic bags; cross-tabulation, for determining the existence of differences among subgroups in demographic terms, and means ranking, for the clarification of which criteria for plastic bags' opting is more salient among consumers.

\section{Results}

It must be stressed that all respondents were consuming plastic bags when they were asked to fill in the questionnaires; data was collected between October and November, 2010. The sample profile consists of 100 valid cases, with most of them females $(60 \%)$ and 15-25 years old (41\%). The second most important part of the sample includes 26-40 year-old respondents; only one case represents people who are 65 years-old or older (for Brazilian law, such age group is characterized as composed of old persons). The majority of the sample is single (54\%), followed by married respondents (37\% of the cases).

Analyzing the amount of study years in the sample is important, for such variable is considered later to oppose distinct groups of consumers in relation to the importance they attribute to plastic bags. Two subgroups of $38 \%$ of the respondents each have college level, respectively complete or incomplete, with 9 cases declaring having post-graduation level; also, none of the cases had elementary education only. Considering familiar monthly income, $33 \%$ of the respondents are included in a 10-30 Brazilian minimum wage level, while a minority of them $(2 \%)$ has 1 minimum age as the family income. Below, the collected data is analyzed.

\subsection{Factor Analysis}

The method used for factor extraction was principal component analysis, with Varimax orthogonal method for factor rotation. Before reporting the results obtained via factor analysis, it is important to stress that such was done in distinct variable groups: degree of ecological consciousness, adoption of sustainable practices, importance attributed to plastic bags and opting criteria for its consumption. Chart 1 shows the concepts and their constituting variables as presented in the adopted questionnaire.

\section{Insert Table 1 Here}

All concepts were assessed using KMO and Bartlett's sphericity test. As suggested by Kaiser (1974), KMO statistics has a minimum recommended value of 0.5 . It is usually said that values between 0.5 and 0.7 are mediocre ones and values between 0.7 and 0.8 are considered as good, while values between 0.8 and 0.9 are considered as very good and values above 0.9 are regarded as excellent (Hutcheson \& Sofroniou, 1999). Considering KMO's limits and intervals and the results found, factor analysis renders appropriate for all the concepts herein approached, as all statistics are higher than 0.5 for cases (in three of them, this value is good).

The criterion used for factor extracting was eigenvalues higher than 1. Based on this, the total number of factors was distinct for the different concepts herein studied. When regarding the first concept (Degree of ecological consciousness), only one factor presented an eigenvalue higher than 1, which explained $60.99 \%$ of the total variance. Similarly, four factors were obtained for both second and third concepts (respectively, Adoption of sustainable practices and Importance attributed to plastic bags), which explained 59.51\% (second concept) and $75.91 \%$ (third concept) of elements' total variance. At last, for the fourth concept (Opting criteria for consumption of plastic bags), two factors were identified, explaining $63.69 \%$ of total variance. As the other factors did not respond for the variance of at least one variable, they were not considered in the present study. Such decision was adopted considering the orientation by Hair, Anderson, Tatham, \& Black (1995), according to whom a factor solution is satisfactory when it represents at least $60 \%$ of variables' total variance. With this in mind, it can be concluded that the observed results are adequate for all four concepts herein investigated.

As mentioned earlier, Varimax rotation was considered for a better interpretation of the factors. With few exceptions, factor loads resulting from factor analysis are above .50. Those that did not reach this value, though, were maintained in the study, as their values are above the minimum level (.30), considering the orientations by Hair et al. (1995). In order to illustrate the results obtained via factor analysis, Chart 2 briefly presents the variables that correspond to each of the factor that compose a concept. Besides this, Chart 2 also shows the names given to each of the obtained factors. Such names were given based on the evaluation of the variables that compose each factor. 
Insert Table 2 Here

\subsection{Cluster Analysis}

Given that the central aim of the present study is the identification of the importance attributed for plastic bags by consumers of a city in the countryside of the Brazilian State of São Paulo, cluster analysis provides a fundamental tool for statistical analysis.

In order to offer a better base for result clustering, two analyzes were preformed, namely, hierarchical and non-hierarchical cluster analysis. The first analysis provided an adequate number of groups for the study. Afterwards, the second analysis was processed in order to reach a solution for case cluster in relation to the importance attributed to plastic bags.

For hierarchical cluster analysis, the adopted input was the mean of each of the factors obtained from factor analysis for Concept 3 (Importance attributed to plastic bags). Ward's method was employed, as well as the square of the Euclidean distance's measure. The hierarchical analysis resulted in two distinct clusters. With an ideal number of clusters for the present study, non-hierarchical analysis was performed in order to check for a better cluster composition. From 100 valid cases herein obtained, 50 represent cluster 1 and the remaining 50, cluster 2 .

Tables 1 and 2 show descriptive statistics for each cluster, providing the basis for naming them. From Table 1, it can be concluded that plastic bag consumers from cluster 1 attribute a low importance for such product, as the observed mean for the factors is generally low. Considering that the mean for factor 1 was 1.41 and it is the factor that best explains the concept, cluster 1 can be classified as "consumers who attribute low importance to plastic bags".

\section{Insert Table 4 Here}

Table 2 shows higher means compared to cluster 1 for the factors analyzed. Therefore, it can be concluded that plastic bag consumers representing cluster 2 attribute median importance for such product, as the mean of the factor that best explains Concept 3 (Importance attributed to plastic bags) is 2.62. For such reason, cluster 2 is named as "consumers who attribute median importance to plastic bags".

\section{Insert Table 5 Here}

\subsection{Cross Tabulation Analysis}

Cross-analyzes were performed in order to assess socio-demographic profiles of plastic bags consumers who attribute high or low importance to such product, so that their degree of ecological consciousness and adoption of sustainable practices can be comprehended. In regard of the cross-tabulation of respondents' gender and low importance attributed to plastic bags, $34 \%(\mathrm{n}=17)$ are men. On the other hand, $54 \%$ of respondents who attribute median importance to plastic bags are women.

Besides this, among those who attribute low importance to plastic bags, most are aged 15-25 years old (48\%). For respondents who attribute median importance to the same product, most are aged 26-40 years old; this represents $38 \%$ of such cluster's cases.

Still for cluster 1 (respondents who attribute low importance to plastic bags), 52\% are single; the same was observed for respondents who attribute median importance to plastic bags (cluster 2). Additionally, cluster 1 respondents have, at most, complete college level (42\%), while most of cluster 2 respondents did not complete college (34\%).

Cross-tabulations of respondents' number of children and importance attributed to plastic bags show that in cluster 1 , most respondents do not have children $(48 \%, n=24)$; the same was observed for cluster 2 . The last socio-demographic variable is monthly family income. For those who attribute low importance to plastic bags, most have a 5-10 minimum wage monthly family income (30\%), while $40 \%$ of cluster 2 respondents have a 10-30 minimum wage monthly family income.

With regard to respondents' degree of ecological consciousness, cluster 1 was composed of $74 \%$ of consumers who displayed a high rate of such consciousness (among 3 and 5). For respondents who attribute low importance to plastic bags, $70 \%$ displayed the same degree of ecological consciousness.

Finally, for the adoption of sustainable practices, $96 \%$ of consumers who attribute low importance to plastic bags (cluster 1) displayed a high rate of such adoption; for cluster 2, most of respondents also displayed high rates (among 3-5) of adoption of sustainable practices, 94\%. 


\subsection{Means Ranking}

In this analysis, criteria adopted by plastic bag consumers are assessed, regarding the option for such consumption. Concept 4 (Opting criteria for consumption of plastic bags), as herein reported, is represented by the questions showed in Table 3, where descriptive statistics of such variables are presented in descending order of mean.

As showed in Table 3, the most withstanding criterion was the absence of options other than plastic bags. Afterwards, the most mentioned criteria were based on household reusing, accessibility, product's lack of cost, unknowing of alternatives and, finally, product's resistance.

\section{Insert Table 6 Here}

In the same logic as presented above, descriptive statistics of variables aforementioned are presented for clusters 1 and 2. Consumers who attribute low importance to plastic bags (cluster 1) showed the same mean ordination than the total sample. For cluster 2 respondents (consumers who attribute median importance to plastic bags), the most mentioned criteria was the possibility of reusing.

\section{Final Considerations}

The present study aimed to investigate the importance attributed to plastic bags by consumers of a city in the countryside of the Brazilian state of São Paulo. Additionally, the present investigation aimed to check for differences between clusters of consumers who attributed high or low importance to such product, according to certain socio-demographic variables, as well as according to their degree of ecological consciousness and their adoption of sustainable practices.

The results from the statistical analyzes are summarized in Table 3. Cluster analyzes were performed based on Concept 3 (Importance attributed to plastic bags), resulting in the formation of two homogeneous groups. This result was not consistent with the central hypothesis, according to which most respondents attribute high importance to plastic bags. Otherwise, it was found that half of the respondents attribute low importance to plastic bags, while others attribute median importance to such product.

\section{Insert Table 3 Here}

Secondary hypothesis 1,2 and 3 are confronted with the obtained results from cross-tabulation. The results of cross-analysis between the degree of ecological consciousness and demographic data is shown in Chart 3 , in order to clarify such degree for each group of plastic bag consumers, subdivided according to importance attributed to such product and considering the factor that best explains each of the concepts herein covered.

Finally, with respect to the study's last hypothesis, it was verified that the most withstanding criterion was the lack of alternative choices than plastic bags in business establishments. Separate cluster analyzes, however, showed that consumers who attribute median importance to plastic bags opt so for, mostly, household reusing. For those who attribute low importance to the product, criteria ordering remained the same as for the total sample, which partially confirms the hypothesis.

Some limitations regarding the present study were observed during the development of field research and may somehow have influenced the results and solutions obtained. The defined target population for the study does not cover all social sectors and classes. In addition, the sample can be a limiting factor in research, as its non-probabilistic nature makes impossible that results can be replicated to the population investigated, corresponding only to the sample under consideration.

Suggestions for future studies comprise the replication of this research in different samples and in different target populations, as well as in other cities, in order to prove the validity of the results. Additionally, the inclusion of a cost variable may prove very interesting for future research, since one of the criteria cited for opting for the consumption of plastic bags was the lack of cost associated with the product.

\section{References}

Albuquerque, J. L. (2009). Gestão ambiental e responsabilidade social: Conceitos, ferramentas e aplicações. São Paulo: Atlas.

Barbosa, L. (2004). Sociedade de consumo. Rio de Janeiro: Jorge Zahar.

Bertolini, G. R. F., \& Possamai, O. (2005). Proposta de instrumento de mensuração do grau de consciência ambiental, do consumo ecológico e dos critérios de compra dos consumidores. Org - Revista de Ciência \& Tecnologia, 13(25), 17-25. [Online] Available: http://www.unimep.br/phpg/editora/revistaspdf/rct25art02.pdf

Bizzotto, A. (2009). País produz 18 bilhões de sacolas plásticas: De cada 10 unidades, 8 vão para aterros; Pouco 
estudada, tecnologia alternativa divide opinião. (2009, February 27). O Estado de São Paulo, p. 12. [Online] Available: http://www.estadao.com.br/noticias/vidae,pais-produz-18-bilhoes-de-sacolas-plasticas,330305,0.htm

Canevarolo, S. V., Jr. (2004). Ciência dos polímeros: Um texto básico para tecnólogos e engenheiros. São Paulo: Artliber.

Caridade, A. V. S. (2006). Práticas de gestão estratégica e aderência ao método sigma: Um estudo de caso no setor de celulose e papel. Unpublished master's thesis, Universidade de São Paulo. [Online] Available: http://www.teses.usp.br/teses/disponiveis/12/12139/tde-22092006-191026/en.php

Chryssohoidis, G. M., \& Krystallis, A. (2007). Organic consumer's personal values research: Testing and validating the list of values (LOV) scale and implementing a value based segmentation task. Food Quality and Preference, 16(7), 585-599. http://dx.doi.org/10.1016/j.foodqual.2005.01.003

Demajorovic, J. (2003). Sociedade de risco e responsabilidade socioambiental: Perspectivas para a educação corporativa. São Paulo: Senac.

Fabro, A. T., Lindemann, C., \& Vieira, S. C. (2007). Utilização de sacolas plásticas em supermercados. Revista Ciências do Ambiente On-line, 3(1), 15-23. [Online] Available: http://sistemas.ib.unicamp.br/be310/index.php/be310/article/viewFile/70/46

Gale, B. T. (1996). Gerenciando o valor do cliente: Criando qualidade e serviços que os clientes podem ver. São Paulo: Pioneira.

García, M. S. A., Durana, C. A. E. G., Abando, J. C., \& Molina, A. V. (2003). El consumidor ecológico: Un modelo de comportamiento a partir de la recopilación y análisis de la evidencia empírica. Distribución y Consumo, 13, 1-53. [Online] Available: http://educamarketing.unex.es/asignaturas/litm/mkecol/lecturas/consumidor_ecol\%C3\%B3gico.pdf

Gilg, A., Barr, S., \& Ford, N. (2005). Green consumption or sustainable lifestyles? Identifying the sustainable consumer. Futures, 37 (6), 481-504. http://dx.doi.org/10.1016/j.futures.2004.10.016

Hair, J. F., Anderson, R. E., Tatham, R. L., \& Black, W. C. (1995). Multivariate data analysis. Upper Saddle Rever: Prentice Hall.

Hopwood, B., Mellor, M., \& O'brien, G. (2005). Sustainable development: Mapping different approaches. Sustainable Development, 13(1), 38-52. http://dx.doi.org/10.1002/sd.244

Hutcheson, G., \& Sofroniou, N. (1999). The multivariate social scientist. London: Sage.

Instituto Akatu. (2010). [Online] Available: http://www.akatu.org.br (February 17, 2011)

Kaiser, H. F. (1974). An index of factorial simplicity. Psychometrika, 39(1), 31-36. http://dx.doi.org/10.1007/BF02291575

Lages, N., \& Vargas Neto, A. V. (2002). Mensurando a consciência ecológica do consumidor: Um estudo realizado na cidade de Porto Alegre. Anais ENANPAD, 26. [CD-ROM].

Lea, S. E. G. (1978). The psychology and economics of demand. Psychological Bulletin, 85 (3), 441-466.

Malhotra, N. K. (1996). Marketing research: An applied orientation. Upper Saddle River: Prentice Hall.

Montaigne, F. A. A. (2002). Terra pede ajuda: O que será de nós se ela acabar? (2002, September). National Geographic Brazil.

Moura, L. A. (2003). A economia ambiental (2nd ed.). São Paulo: Juarez de Oliveira.

Nobre, M., \& Amazonas, M. C. (2002). Desenvolvimento sustentável: A institucionalização de um conceito. Brasília, DF: IBAMA.

Ottman, J. A. (1994). Marketing verde. São Paulo: Makron Books.

Raposo, S. (2003). Consumo consciente: Economizar água e energia e comprar produtos ecológicos são algumas maneiras de contribuir com a preservação ambiental. [Online] Available: http://www.salveoplaneta.com.br/art_01.htm (August 30, 2003).

Ritch, E., Brennan, C., \& MacLeod, C. (2009). Plastic bag politics: modifying consumer behaviour for sustainable development. International Journal of Consumer Studies, 33, 168-174. http://dx.doi.org/10.1111/j.1470-6431.2009.00749.x

Shurum, L. J., Mccarty, J. A., \& Lowrey, T. M. (1995). Buyer characteristics of the green consumer and their implication for advertising strategy. Journal of Advertising, 24(2), 71-82. 
Swait, J., \& Adamowicz, W. (2001). Choice environment, market complexity, and consumer behavior: a theoretical and empirical approach for incorporating decision complexity into models of consumer choice. Organizational Behavior and Human Decision Processes, $86 \quad$ (2), 141-167. http://dx.doi.org/10.1006/obhd.2000.2941

Tinoco, J. E. P. (2004). Contabilidade e gestão ambiental. São Paulo: Atlas.

Table 1. Concepts and their composition

\section{Concept 1: Degree of ecological consciousness}

1-I have a great knowledge regarding the acid rain problem.

2- I have a great knowledge regarding the greenhouse effect problem.

3- I have a great knowledge regarding the deforestation problem.

4- I have a great knowledge regarding the nuclear waste problem.

5 - I have a great knowledge regarding super population-related problems.

6- I have a great knowledge regarding the water pollution problem.

7- I have a great knowledge regarding environmental problems.

8- I have a great knowledge regarding plastic bags and the effects of their disposal in the environment.

\section{Concept 2: Adoption of sustainable practices}

9-Before disposing something, I think about how I could reuse it.

10-I put recyclable garbage apart, such as paper, plastic, aluminum, glass or ferrous metals.

11-I avoid burning household garbage (plastic, Styrofoam, organic scraps).

12-When I am shaving or brushing my teeth, I usually do not leave the faucet open.

13-When I leave a room, I turn lights and TV off.

14-I use the laundry machine or the dishwasher only at their maximum load capacity.

15-I care about not littering the streets.

16-I use both sides of paper sheets and reuse paper scraps.

17-When I go shopping, I take companies' environmental posture into consideration.

18-I tend to buy products and packages made of recycled or recyclable materials.

19-Before buying something, I usually check products' tags and packages in order to identify if it is environmentally correct.

20-I always buy organic products.

21- I always buy biodegradable cleaning products.

22- I always buy energy-safe lamps and appliances.

23-I usually spend more money with products that do not pollute the environment.

24-When I go shopping and find a product which tag informs it was made in an environmentally correct way, I feel motivated to buy it.

Concept 3: Importance attributed to plastic bags

25-I believe there are substantial differences between plastic bags and ones made of other materials (oxybiodegradables, biodegradables, cloth, cardboard).

26-I know exactly what I look for when I opt for plastic bags.

27-In case a business establishment did not offer plastic bags, I would opt for another one that did so.

28- In case a business establishment charged for plastic bags, I would opt for another one that did not do so.

29- In case a business establishment charged for plastic bags, I would adopt alternative ways to transport what I bought.

30- In case every business establishments charged for plastic bags, I would adopt alternative ways to transport what I bought.

31-I believe plastic bags are the best alternative for transporting what I buy.

32-I insist on plastic bags under any circumstances.

Concept 4: Opting criteria for consumption of plastic bags

33-I opt for plastic bags because I believe they are more sensible than the other alternatives. 
Continued (Table 1)

34- I opt for plastic bags because I believe they are more resistant than the other alternatives.

35- I opt for plastic bags because I believe they are more accessible than the other alternatives.

36- I opt for plastic bags in order to reuse them at home.

37- I opt for plastic bags because they are free.

38- I opt for plastic bags because I do not have other options at hand.

39- I opt for plastic bags because I do not know other alternatives that can substitute them.

Table 2. Summary of results obtained through factor analysis

\begin{tabular}{|c|c|c|}
\hline Concept & Factors & Factors' Name and Description \\
\hline $\begin{array}{l}\text { Degree of Ecological } \\
\text { consciousness }\end{array}$ & Factor 1 & $\begin{array}{l}\text { Ecological consciousness: mean of responding to variables } \\
1,2,3,4,5,6,7 \text { and } 8\end{array}$ \\
\hline \multirow{4}{*}{$\begin{array}{l}\text { Adoption of } \\
\text { sustainable practices }\end{array}$} & Factor 1 & $\begin{array}{l}\text { Sustainable practices within buying process: mean of } \\
\text { responding to variables } 17,18,19,20,21,22,23 \text { and } 24\end{array}$ \\
\hline & Factor 2 & $\begin{array}{l}\text { Sustainable practices within household settings: mean of } \\
\text { responding to variable } 13\end{array}$ \\
\hline & Factor 3 & $\begin{array}{l}\text { Sustainable practices related to energy consumption: mean } \\
\text { of responding to variables } 11,14,15 \text { and } 16\end{array}$ \\
\hline & Factor 4 & $\begin{array}{l}\text { Sustainable practices related to recycling and reusing: mean } \\
\text { of responding to variables } 9,10 \text { and } 12\end{array}$ \\
\hline \multirow{4}{*}{$\begin{array}{l}\text { Importance } \\
\text { attributed to plastic } \\
\text { bags }\end{array}$} & Factor 1 & $\begin{array}{l}\text { Sensibility to charging for plastic bags: mean of responding to } \\
\text { variables } 29 \text { and } 30\end{array}$ \\
\hline & Factor 2 & $\begin{array}{l}\text { Importance of business establishments' offering of plastic } \\
\text { bags: mean of responding to variable } 27\end{array}$ \\
\hline & Factor 3 & $\begin{array}{l}\text { Best alternative for carrying bought products; essentiality } \\
\text { character: mean of responding to variables } 31 \text { and } 32\end{array}$ \\
\hline & Factor 4 & $\begin{array}{l}\text { Beliefs and opinions regarding plastic bags: mean of } \\
\text { responding to variables } 25,26 \text { and } 28\end{array}$ \\
\hline \multirow{2}{*}{$\begin{array}{l}\text { Opting criteria for } \\
\text { consumption } \\
\text { plastic bags }\end{array}$} & Factor 1 & $\begin{array}{l}\text { Product's own characteristics: mean of responding to } \\
\text { variables } 33,34,35,37 \text { and } 39\end{array}$ \\
\hline & Factor 2 & $\begin{array}{l}\text { Factors besides product's own characteristics: mean of } \\
\text { responding to variables } 36 \text { and } 38\end{array}$ \\
\hline
\end{tabular}


Table 3. Summary of conclusions obtained from field research

\begin{tabular}{|c|c|c|}
\hline Preliminary Hypotheses & $\begin{array}{l}\text { Post-analysis Conclusion: } \\
\text { Confirmed/Not Confirmed }\end{array}$ & Results \\
\hline $\begin{array}{l}\text { Central Hypothesis: Most of the } \\
\text { respondents attribute a high } \\
\text { importance to plastic bags, } \\
\text { displaying a high level of } \\
\text { involvement in its consumption's } \\
\text { process. }\end{array}$ & NOT CONFIRMED & $\begin{array}{l}\text { Respondents attribute low to median } \\
\text { importance to plastic bags. }\end{array}$ \\
\hline $\begin{array}{l}\text { Hypothesis 1: Most of plastic bags } \\
\text { consumers do not know } \\
\text { environmental problems in depth. }\end{array}$ & NOT CONFIRMED & $\begin{array}{l}\text { Most of plastic bag consumers }(72 \% \\
\text { of } 100 \text { valid cases) know } \\
\text { environmental problems relatively } \\
\text { well. }\end{array}$ \\
\hline $\begin{array}{l}\text { Hypothesis 2: Respondents that } \\
\text { attribute less importance to plastic } \\
\text { bags are younger, have more study } \\
\text { years and higher income than the } \\
\text { other ones. }\end{array}$ & PARTIALLY CONFIRMED & $\begin{array}{l}\text { Respondents who attribute low } \\
\text { importance to plastic bags are, at } \\
\text { most, female, aged } 15-25 \text { years old, } \\
\text { single, with no children, complete } \\
\text { college level and monthly family } \\
\text { income of 5-10 minimum wages. } \\
\text { Such group has a higher income than } \\
\text { the others. Although this group's } \\
\text { school level is superior and their age } \\
\text { level is inferior compared to the other } \\
\text { group, the hypothesis regarding } \\
\text { income was not confirmed. }\end{array}$ \\
\hline $\begin{array}{l}\text { Hypothesis 3: There is no clear } \\
\text { relationship between respondents' } \\
\text { degree of involvement in the } \\
\text { consumption of plastic bags and } \\
\text { respondents' adoption of sustainable } \\
\text { practices. }\end{array}$ & CONFIRMED & $\begin{array}{l}\text { Most of plastic bag consumers herein } \\
\text { considered display a high rate of } \\
\text { adoption of sustainable practices, } \\
\text { which demystifies the idea that those } \\
\text { who consume plastic bags do not } \\
\text { show responsible, environmental } \\
\text { practices. }\end{array}$ \\
\hline $\begin{array}{l}\text { Hypothesis 4: Most of respondents } \\
\text { opt for plastic bags due to their } \\
\text { gratuity and plausibility for } \\
\text { household reuse. }\end{array}$ & PARTIALLY CONFIRMED & $\begin{array}{l}\text { The majority of respondents opt for } \\
\text { plastic bags because of not having } \\
\text { other option at hand. However, } \\
\text { household reusing proved to be the } \\
\text { most commonly used criterion among } \\
\text { consumers who attribute median } \\
\text { importance to the consumption of } \\
\text { plastic bags. }\end{array}$ \\
\hline
\end{tabular}


Table 4. Descriptive statistics for cluster 1

\begin{tabular}{|l|l|l|l|l|l|}
\hline Descriptive Statistics - Cluster 1 & M & Minimum & Maximum & Mean & Standard Deviation \\
\hline Importance attributed to plastic bags & 50 & 1 & 3 & 1.41 & 0.7049 \\
\hline FACTOR 1 & 50 & 1 & 3 & 1.48 & 0.6773 \\
\hline FACTOR 2 & 50 & 1 & 3 & 1.39 & 0.5828 \\
\hline FACTOR 3 & 50 & 2.33 & 5 & 3.619 & 0.8992 \\
\hline FACTOR 4 & 50 & & & & \\
\hline Valid N & & & & & \\
\hline
\end{tabular}

Table 5. Descriptive statistics for cluster 2

\begin{tabular}{|l|l|l|l|l|l|}
\hline Descriptive Statistics - Cluster 2 \\
\hline Importance attributed to plastic bags & $\mathbf{N}$ & Minimum & Maximum & Mean & Standard Deviation \\
\hline FACTOR 1 & 50 & 1 & 5 & 2.62 & 1.272 \\
\hline FACTOR 2 & 50 & 1 & 5 & 3.46 & 1.034 \\
\hline FACTOR 3 & 50 & 1 & 4 & 2.04 & 0.844 \\
\hline FACTOR 4 & 50 & 1.67 & 4.33 & 3.25 & 0.6499 \\
\hline Valid N & 50 & & & & \\
\hline
\end{tabular}

Table 6. Ordination of opting criteria for consumption of plastic bags

\begin{tabular}{|l|l|l|l|l|l|l|}
\hline & I opt for plastic bags... & $\begin{array}{l}\text { Number of } \\
\text { Valid Cases }\end{array}$ & Minimum & Maximum & Mean & $\begin{array}{l}\text { Standard } \\
\text { Deviation }\end{array}$ \\
\hline $\mathbf{1}$ & $\begin{array}{l}\text { Because I do not have other options at } \\
\text { hand }\end{array}$ & 100 & 1 & 5 & 3.39 & 1.385 \\
\hline $\mathbf{2}$ & In order to reuse them at home & 100 & 1 & 5 & 3.37 & 1.323 \\
\hline $\mathbf{3}$ & $\begin{array}{l}\text { Because I believe they are more } \\
\text { accessible than the other alternatives }\end{array}$ & 100 & 1 & 5 & 3.16 & 1.475 \\
\hline $\mathbf{4}$ & Because they are free & 100 & 1 & 5 & 3.10 & 1.389 \\
\hline $\mathbf{5}$ & $\begin{array}{l}\text { Because I believe they are more sensible } \\
\text { than the other alternatives }\end{array}$ & 100 & 1 & 5 & 2.51 & 1.521 \\
\hline $\mathbf{6}$ & $\begin{array}{l}\text { Because I do not know other } \\
\text { alternatives that can substitute them }\end{array}$ & 100 & 1 & 5 & 1.95 & 1.274 \\
\hline $\mathbf{7}$ & $\begin{array}{l}\text { Because I believe they are more } \\
\text { resistant than the other alternatives }\end{array}$ & 100 & 1 & 5 & 1.76 & 1.026 \\
\hline
\end{tabular}

